\title{
Proton transfer reaction time-of-flight mass spectrometry: A high- throughput and innovative method to study the influence of dairy system and cow characteristics on the volatile compound fingerprint of cheeses
}

\author{
M. Bergamaschi, ${ }^{\star} \dagger$ F. Biasioli, $\dagger^{1}$ L. Cappellin, $\dagger$ A. Cecchinato, ${ }^{*}$ C. Cipolat-Gotet, ${ }^{*}$ A. Cornu, $¥ \S$ F. Gasperi, $\dagger$ \\ B. Martin, $¥ \S$ and $\mathbf{G}$. Bittante* \\ *Department of Agronomy, Food, Natural Resources, Animals and Environment (DAFNAE), University of Padova, Viale dell'Università 16, \\ 35020 Legnaro (PD), Italy \\ †Department of Food Quality and Nutrition, Research and Innovation Centre, Fondazione Edmund Mach (FEM) Via E. Mach 1 , \\ 38010 San Michele all'Adige (TN), Italy \\ łINRA, UMR 1213 Herbivores, F-63122 Saint-Genès Champanelle, France \\ $\S$ Clermont Université, VetAgro Sup, BP 10448, F-63000 Clermont-Ferrand, France
}

\begin{abstract}
The aim of this work was to study the effect of dairy system and individual cow-related factors on the volatile fingerprint of a large number of individual model cheeses analyzed by proton transfer reaction time-offlight mass spectrometry (PTR-ToF-MS). A total of 1,075 model cheeses were produced using milk samples collected from individual Brown Swiss cows reared in 72 herds located in mountainous areas of Trento province (Italy). The herds belonged to 5 main dairy systems ranging from traditional to modern and the cows presented different daily milk yields $(24.6 \pm 7.9$ $\left.\mathrm{kg} \times \mathrm{d}^{-1}\right)$, stages of lactation (199 $\pm 138 \mathrm{~d}$ in milk), and parities $(2.7 \pm 1.8)$. The PTR-ToF-MS revealed 619 peaks, of which the 240 most intense were analyzed, and 61 of these were tentatively attributed to relevant volatile organic compounds on the basis of their fragmentation patterns and data from the literature. Principal component analysis was used to convert the multiple responses characterizing the PTR-ToF-MS spectra into 5 synthetic variables representing $62 \%$ of the total information. These principal components were related to groups of volatile compounds tentatively attributed to different peaks and used to investigate the relationship of the volatile compound profile obtained by PTR-ToF-MS to animal and farm characteristics. Lactation stage is related to 4 principal components which brought together $52.9 \%$ of the total variance and $57.9 \%$ of the area of analyzed peaks. In particular, 2 principal components were positively related to peaks tentatively attributed to aldehydes and ketones and negatively related to alcohols, esters, and acids, which displayed a linear increase during lactation. The second
\end{abstract}

Received May 11, 2015.

Accepted August 29, 2015.

${ }^{1}$ Corresponding author: franco.biasioli@fmach.it principal component was affected by dairy system; it was higher in the modern system in which cows received total mixed rations. The third principal component was positively related to daily milk production. In summary, we report the first application of this innovative, high-throughput technique to study the effects of dairy system and individual animal factors on volatile organic compounds of model cheeses. Individual cheesemaking procedures together with this spectrometric technique open new avenues for genetic selection of dairy species with respect to both milk and cheese quality.

Key words: volatile compound fingerprint, cheese smell, proton transfer reaction time of flight mass spectrometry (PTR-ToF-MS), new phenotypes, dairy system

\section{INTRODUCTION}

Flavor is an important driver of cheese purchase and consumption (Drake et al., 2008; Childs and Drake, 2009). Food quality assessment now requires low-cost, rapid, nondestructive testing techniques that can be applied to small samples (Rodriguez-Saona et al., 2006). Analytical tools that enable qualitative fingerprinting of a wide range of dairy products are particularly attractive, and among these there is growing interest in direct injection spectrometric techniques, particularly proton transfer reaction time of flight mass spectrometry (PTR-ToF-MS; Biasioli et al., 2011). The PTRToF-MS is based on the ionization of volatile organic compounds (VOC) with a proton affinity higher than water upon reaction with hydronium ions $\left(\mathrm{H}_{3} \mathrm{O}^{+}\right)$ and subsequent detection by a high-resolution time of flight mass analyzer. In particular, this apparatus is composed of a hollow cathode discharge ion source in which $\mathrm{H}_{3} \mathrm{O}^{+}$reagent ions are produced from water vapor used as reagent gas; a drift tube where the VOC to be analyzed are continuously injected and ionized 
by proton-transfer reaction with $\mathrm{H}_{3} \mathrm{O}^{+}$ions; and a quadruple mass analyzer where the ions are detected. Unlike other techniques with better identification capability, such as GC-MS, PTR-ToF-MS allows direct injection of the headspace without extraction or preconcentration steps, and has a shorter analysis time (only a few seconds per sample) and greater sensitivity. As in other headspace gas chromatographic analyses, it is also nondestructive, does not require chemicals, and permits on-line monitoring of VOC, whereas the resulting spectral information can provide a very detailed description of samples, which is useful for characterizing food quality and typicality (Biasioli et al., 2011; Cappellin et al., 2012a). For example, PTR-ToF-MS has applications in food science and technology, dairy products in particular, for monitoring VOC production in cheese during ripening (Aprea et al., 2007; Fabris et al., 2010; Soukoulis et al., 2010), correlating the cheese volatile profile with the sensory characterization of cheese flavor and odor (Biasioli et al., 2006), and for investigating the geographical origin and the typicality of cheese (Galle et al., 2011).

Cow management and breed, animal genetics, season, and technological factors influence milk characteristics and, as a consequence, cheese quality and sensory properties (Coulon et al., 2004; Bittante et al., 2011a,b). Studies have been carried out on the influence of dairy cow feeding on the sensory properties of cheese (Martin and Coulon, 1995b; Cornu et al., 2009), but little is known about the effects of individual animal-related factors on cheese flavor.

This work was part of a large research project (Cowplus Project) aimed at developing new phenotypes of dairy cow depicting the relationships between animal characteristics, milk quality, cheesemaking aptitude, and cheese sensory traits. In the frame of this project, Cipolat-Gotet et al. (2013) proposed a method to produce model cheeses from individual milk samples that has proven to be particularly useful in determining the cheesemaking aptitude of milk and in allowing for the study of both individual phenotypic sources of variation (DIM, parity, milk yield) and environmental (dairy system) factors on a large scale. The individual model cheese-manufacturing process was also used to estimate genetic parameters of the cheesemaking properties of milk and of daily cheese production through direct measurement (Bittante et al., 2013) or Fouriertransform infrared spectrometry prediction (Ferragina et al., 2013, 2015; Bittante et al., 2014). Cipolat-Gotet et al. (2013) applied the model cheesemaking procedure to 1,264 cows from 85 herds to study cheese yield as well as the recovery of individual milk components in the curd and also to quantify the ratios between the curd contents of fat, protein, DM, and energy versus the content of the corresponding nutrient in the processed milk. Those authors found a significant effect of herd and individual animal factors.

As part of the same Cowplus Project, Bergamaschi et al. (2015) showed that this individual cheesemaking procedure could also be used for qualitative studies of individual cheeses. In a pilot study on a sample of 150 individual model cheeses obtained from 30 herds, they studied the VOC profile of ripened cheeses using solidphase microextraction GC-MS (SPME/GC-MS) and characterized the VOC profile of ripened cheeses: 55 compounds were identified and an exploitable variability according to dairy system and individual animal characteristics was observed. Moreover, SPME/GC-MS analysis of selected cheeses offers the possibility to support PTR-ToF-MS fingerprint analysis in a large number of samples (Cappellin et al., 2012a).

The aims of the current work were (1) to study the potential of PTR-ToF-MS for rapid characterization of cheeses on the basis of their volatile fingerprint, and (2) to analyze the effects of dairy system and individual cow characteristics on the volatile compounds of cheese using a large number of individual model cheeses.

\section{MATERIALS AND METHODS}

\section{Field Data}

To carry out this study, also part of the Cowplus Project, a total of 1,075 Italian Brown Swiss cows reared in 72 herds located in Trento Province (Italy) were selected. Fifteen cows were chosen randomly from each herd and sampled once on the same day: the herds were sampled year round to cover all seasons and rearing conditions. The sampled cows presented different milk yields $\left(24.6 \pm 7.9 \mathrm{~kg} \times \mathrm{d}^{-1}\right)$, stages of lactation $(199 \pm 138$ DIM $)$, and parities $(2.7 \pm 1.8)$. The sampling procedure is described in detail by Cipolat-Gotet et al. (2012) and Cecchinato et al. (2013). The production environments, which varied in terms of production level, destination of milk, modernization of structures, and management, are discussed by Sturaro et al. (2013). The selected dairy farms of this Alpine area $(825 \pm 334$ $\mathrm{m}$ above sea level) used different dairy management strategies, with variations in facilities, feedstuff distribution, use of silages, and transhumance to temporary summer Alpine pastures.

Traditional dairy farms were those dairy systems utilizing small barns, tied animals milked at the stall, calving concentrated mainly in autumn, transhumance of cows and heifers to Alpine pastures for the summer, and feed mainly composed of hay and compound feed. These were either with or without automatic feeders at the manger (traditional with automatic feeders, 9 farms, 
or traditional without automatic feeders, 12 farms, respectively). Modern dairy farms were characterized by features of intensive systems: larger, modern facilities, loose animals, milking parlors, year-round calving, use of TMR, with or without maize silage (modern TMR with silage, 7 farms, or modern TMR without silage, 14 farms, respectively). Intermediate dairy systems were those farms with modern facilities but traditional feeding management composed of hay and compound feed (modern hay + compound feed, 30 farms).

Collection, refrigeration, transport, and storage of milk samples were standardized with the aim of minimizing differences among herds (corresponding to sampling dates). After collection, all milk samples (without preservatives) were immediately refrigerated $\left(4^{\circ} \mathrm{C}\right)$ and processed into cheeses within $20 \mathrm{~h}$ at the cheesemaking laboratory of the Department of Agronomy, Food, Natural Resources, Animals and Environment (DAFNAE) of the University of Padova (Legnaro, Padova, Italy). Fat, protein, and casein percentages were determined using a MilkoScan FT6000 apparatus (Foss Electric A/S, Hillerød, Denmark). The pH was measured using a Crison Basic 25 electrode (Crison, Barcelona, Spain). Somatic cell count was obtained from the Fossomatic FC counter (Foss) then converted to SCS by logarithm transformation (Ali and Shook, 1980). Information on the cows (DIM, parity, and milk yield) was provided by the Breeders Federation of Trento Province (Trento, Italy).

Descriptive statistics of milk composition traits are summarized in Table 1. Milk composition reflected the good milk quality typical of Brown Swiss cows (Cecchinato et al., 2015).

The modern dairy systems produced more milk than the traditional systems. In particular, modern farms with TMR without silage had higher milk yields (30.0 $\pm 8.4 \mathrm{~kg} \times \mathrm{d}^{-1}$ ) than the traditional farms without an automatic feeder $\left(19.5 \pm 7.3 \mathrm{~kg} \times \mathrm{d}^{-1}\right)$. The cows reared in traditional dairy farms without automatic feeder produced milk with lower fat $(4.2 \pm 0.7 \%)$ and protein $(3.7 \pm 0.4 \%)$ contents than the cows reared in the modern dairy systems with TMR and with maize silage $(5.0 \pm 1.2 \%$ fat and $3.9 \pm 0.4 \%$ protein, respectively).

\section{Cheesemaking Procedure}

Model cheeses were manufactured using raw milk from individual cows according to the method described by Cipolat-Gotet et al. (2013) that resembles the industrial process often used to produce full-fat, 2-mo ripened cheese. No adjustment of the procedure was applied to take into account the differences in composition of milk samples because the main aim of the project was to fully analyze the individual variability. Briefly, 1,500 mL of milk were heated, cultured, and mixed with rennet solution to a final concentration of $51.2 \mathrm{IU} / \mathrm{L}$. The resulting curd was cut, drained, shaped in wheels, pressed, salted, and weighed. The small wheels produced for the purpose of our study were ripened for $60 \mathrm{~d}$ and then weighed and analyzed. The fat, protein, and DM contents of the whole cheeses were measured using a FoodScan apparatus (Foss). The pH was measured at $20^{\circ} \mathrm{C}$ by inserting a Crison Basic 20 electrode (Crison) into each model cheese. A cylindrical sample $1.1 \mathrm{~cm}$ in diameter and about $3.5 \mathrm{~cm}$ in height was taken from the center of each model cheese and conserved at $-80^{\circ} \mathrm{C}$ until VOC analysis.

Descriptive statistics of the cheese compositions are presented in Table 1. Dairy system did not significantly

Table 1. Descriptive statistics of cow parity, DIM, and milk yield, and of milk and cheese composition

\begin{tabular}{|c|c|c|c|c|c|}
\hline Trait & $\mathrm{N}$ & Mean & $\mathrm{SD}$ & $\mathrm{P} 5^{1}$ & $\mathrm{P} 95^{1}$ \\
\hline Parity, n & 1,075 & 2.7 & 1.8 & 1.0 & 6.0 \\
\hline DIM, $d$ & 1,070 & 198 & 138 & 25 & 447 \\
\hline Milk yield, $\mathrm{kg} \times \mathrm{d}^{-1}$ & 1,056 & 24.6 & 7.9 & 12.5 & 38.3 \\
\hline \multicolumn{6}{|l|}{ Milk composition } \\
\hline Fat, \% & 1,073 & 4.4 & 0.9 & 3.2 & 5.9 \\
\hline Protein, $\%$ & 1,073 & 3.8 & 0.4 & 3.1 & 4.5 \\
\hline Fat/protein & 1,073 & 1.18 & 0.25 & 0.86 & 1.58 \\
\hline Casein/protein & 1,071 & 0.769 & 0.018 & 0.750 & 0.787 \\
\hline $\mathrm{SCS}^{2}$ & 1,071 & 3.03 & 1.86 & 0.21 & 6.21 \\
\hline $\mathrm{pH}$ & 1,073 & 6.63 & 0.09 & 6.49 & 6.77 \\
\hline \multicolumn{6}{|l|}{ Cheese composition } \\
\hline Fat, \% & 935 & 38.2 & 4.4 & 31.6 & 45.6 \\
\hline Fat in DM, \% & 935 & 47.7 & 4.7 & 40.7 & 54.8 \\
\hline Protein, $\%$ & 935 & 27.1 & 4.1 & 20.4 & 33.2 \\
\hline DM, \% & 935 & 80.1 & 4.7 & 71.8 & 86.9 \\
\hline $\mathrm{pH}$ & 1,071 & 5.16 & 0.18 & 4.85 & 5.44 \\
\hline
\end{tabular}


Table 2. Structure of the proton transfer reaction time of flight mass spectrometry data set (1,075 model cheeses from individual cows)

\begin{tabular}{lccrrr}
\hline & & & \multicolumn{2}{c}{ Incidence (\%) on database } \\
\cline { 4 - 6 } Data set & $\begin{array}{c}\text { Spectral } \\
\text { peaks (n) }\end{array}$ & $\begin{array}{c}\text { Spectral } \\
\text { intensity }\left(\mathrm{ppb}_{\mathrm{v}}{ }^{1}\right)\end{array}$ & $\mathrm{A}$ & $\mathrm{B}$ & $\mathrm{C}$ \\
\hline A: initial data set & 619 & $49,723,176$ & 100.0 & - & - \\
B: only peaks above 1 $\mathrm{ppb}_{\mathrm{v}}$ threshold & 317 & $49,594,607$ & 99.7 & 100.0 & - \\
C: without interference ions & 240 & $28,652,992$ & 57.6 & 57.8 & 100.0 \\
D: only peaks tentatively identified & 61 & $22,356,325$ & 44.8 & 45.0 & 78.0 \\
\hline${ }^{1} \mathrm{ppb}_{\mathrm{v}}=$ parts per billion by volume. & & & & &
\end{tabular}

influence the gross composition of model cheeses even if, numerically, model cheeses from the modern dairy systems were characterized by a slightly higher level of fat and protein content than those from the traditional systems. Within the modern dairy systems, the farms using TMR and maize silage exhibited a slightly higher fat content. In the 5 mountain dairy systems, cheese $\mathrm{pH}$ ranged from $5.13 \pm 0.20$ (modern hay + compound feed) to $5.21 \pm 0.14$ (modern TMR with silage); the difference between them was not significant.

\section{PTR-ToF-MS}

The headspace of the 1,075 model cheeses was analyzed using a commercial PTR-ToF-MS 8000 instrument (Ionicon Analytik GmbH, Innsbruck, Austria) and a modified version of the method described in detail by Fabris et al. (2010). Briefly, cheese samples were thawed and kept at room temperature (about $20^{\circ} \mathrm{C}$ ) for $6 \mathrm{~h}$, then 3 -g subsamples from each sample were put into glass vials $(20 \mathrm{ml}$, Supelco, Bellefonte, PA) and capped by PTFE/Silicone septa (Supelco). About 75 samples chosen randomly from the 1,075-sample set were measured every day. Conditions in the drift tube were as follows: drift tube temperature $110^{\circ} \mathrm{C}$, drift pressure $211 \mathrm{~Pa}$, and drift voltage $500 \mathrm{~V}$. Internal calibration and peak extraction was performed according to a procedure described by Cappellin et al. (2011), which allowed the identification of 619 peaks and was, in most cases, sufficient for sum formula identification. Absolute headspace VOC concentration expressed as parts per billion by volume $\left(\mathbf{p p b}_{\mathbf{v}}\right)$ was estimated using the formula described by Lindinger et al. (1998) with a constant reaction rate coefficient of the proton transfer reaction of $2 \times 10^{-9} \mathrm{~cm}^{3} / \mathrm{s}$. This method has been shown to be viable for absolute VOC headspace concentration determination (Cappellin at al., 2012b). The use of the same reaction rate coefficient produces a systematic error that is typically negligible and the estimation accuracy can be improved if the actual reaction rate coefficient is known. The relative VOC concentrations between samples is not affected by the value of the reaction rate coefficient.

\section{Statistical Analysis}

The data set comprised 1,075 model cheeses (records) and 619 spectrometric peaks (variables) corresponding to the headspace concentrations of all identified peaks with a defined $m / z$ value (data set A), which had a total spectral intensity of 49,723,176 $\mathrm{ppb}_{\mathrm{v}}$ (Table 2). All peaks below a threshold of $1 \mathrm{ppb}_{\mathrm{v}}$ (302 peaks) were removed from the mass spectra (data set B), and 77 masses (42\% of the total mass spectra intensity) associated with the PTR-ToF-MS ion source and water clusters (possible interference) were excluded before any statistical analysis (data set $\mathrm{C}$ ).

Given that the distribution of all spectra peaks showed a strong positive skewness, the data were transformed: the fraction of each peak plus one was multiplied by $10^{6}$ and expressed as a natural logarithm to obtain a Gaussian-like data distribution. All transformed records that were 3 standard deviations or more outside the mean were considered outliers and substituted by a mean plus 3 standard deviations value before any statistical processing.

Data standardization was performed within each day of analysis ( $15 \mathrm{~d})$ to equalize data variability resulting from the effect of this environmental factor on proton transfer reaction masses; this was also confirmed by a Levene's test (data not shown). Multivariate data treatment (principal component analysis) was applied to the standardized data using Statistica 7.1 (StatSoft, Paris, France) to synthesize the information and to provide a new set of principal components (PC).

Dependent variables were analyzed using the mixed model procedure of SAS (SAS Inst. Inc., Cary, NC) according to the following model:

$$
\begin{gathered}
\mathrm{Y}_{\mathrm{ijklmno}}=\mu+\text { dairy system }_{\mathrm{i}}+\text { HTD }_{\mathrm{j}}(\text { dairy system })_{\mathrm{i}} \\
+ \text { DIM }_{\mathrm{k}}+\text { parity }_{\mathrm{l}}+\text { milk }_{\mathrm{m}}+\text { vat }_{\mathrm{n}}+\mathrm{e}_{\mathrm{ijklmno}},
\end{gathered}
$$


where $\mathrm{Y}_{\mathrm{ijklmno}}$ is the observed trait (first $5 \mathrm{PC}$ and 240 spectrometric peaks); $\mu$ is the overall mean; dairy system $_{\mathrm{i}}$ is the fixed effect of the ith dairy systems $(i=1$ to $5)$; HTDj(dairy system) is the random effect of the jth herd test date ( $\mathrm{j}=1$ to 72 ) within ith dairy systems; $\mathrm{DIM}_{\mathrm{k}}$ (interval from calving to milk sampling) is the fixed effect of the kth classes of DIM $(\mathrm{k}=1$ to 7 ; class 1 $=\leq 50 \mathrm{~d}$, class $2=51$ to $100 \mathrm{~d}$, class $3=101$ to $150 \mathrm{~d}$, class $4=151$ to $200 \mathrm{~d}$, class $5=201$ to $250 \mathrm{~d}$, class $6=$ 251 to 300 , class $7=>300 \mathrm{~d}$ ); parity (order of parity) is the fixed effect of the lth parity ( $1=1$ to 4 or more); milk $_{\mathrm{m}}$ (daily milk yield, $\mathrm{kg} \times \mathrm{d}^{-1}$ ) is the linear covariate of daily milk production; vat ${ }_{n}$ is the fixed effect of the nth experimental vat used for model cheese production ( $\mathrm{n}=1$ to 15$)$; and $\mathrm{e}_{\mathrm{ijk} \text { lmno }}$ is the residual random error term $\sim \mathrm{N}\left(0, \sigma^{2}\right)$. The effect of dairy system was tested using herd test date within dairy system as the error term, whereas other fixed effects were tested on the residual. In addition, orthogonal contrasts were used to test the effects of dairy system and parity.

\section{RESULTS}

\section{VOC Profiling of Model Cheeses Analyzed by PTR-ToF-MS}

A large number of peaks (619) describing volatile organic compounds (Table 2) were obtained from headspace PTR-ToF-MS analysis of individual model cheeses. Data compression was performed considering the 317 most intense peaks with spectrometric area greater than $1 \mathrm{ppb}_{\mathrm{v}}$, which represented $99.7 \%$ of the total spectral intensity (Table 2). After elimination of 77 possibly interfering ions, 240 peaks were still available.

To aid spectra interpretation (Supplementary Table S1; http://dx.doi.org/10.3168/jds.2015-9803), the fragmentation pattern of 61 relevant compounds, representing $78.0 \%$ of the total spectral intensity of the compressed data set without interfering ions (Table 2), were retrieved from available GC-MS data on the same model cheeses (Bergamaschi et al., 2015) or from the literature (Fabris et al., 2010; Soukoulis et al., 2010; Galle et al., 2011). Where unavailable, data from the fragmentation pattern was used to identify measured peaks.

Descriptive statistics of the proton transfer reaction peaks detected in the model cheeses are in the supplementary material section (Supplementary Table S2; http://dx.doi.org/10.3168/jds.2015-9803). The most intense peaks detected were at $m / z 43.018,43.054$, 61.028 , and 45.033 , with a mean value in natural logarithm of 11.3, 11.1, 11.0, and 10.9, respectively (Supplementary Table S2). We attributed these spectrometric fragments to alkyl fragments, acetic acid, and ethanal.

\section{New Synthetic Variables Associated with Cheese VOC}

Multivariate data treatment was performed to convert multiple responses (240 masses) into a small number of variables. All the correlation coefficients between the first $5 \mathrm{PC}$ and the 240 individual masses are shown in the supplementary data section (Supplementary Table S3; http://dx.doi.org/10.3168/jds.2015-9803). The 5 first PC together explained $61.5 \%$ of the total variability of the original variables; the major positive and negative peaks of the PC are shown in Table 3 . The first PC explained $28.3 \%$ of the total original variance. The other 4 PC explained 10.9, 8.6, 7.6, and $6.1 \%$, respectively.

\section{The Effects of Farming System}

Results from an ANOVA, reported in Table 4, show the effects of dairy system, herd test date, and individual cow-related factors on the 5 extracted PC. The effect of individual herds within dairy system was greater for both PC3 and PC5 because the variance explained by herd test date represented 53 and $48 \%$ of total variance, whereas for PC2, PC1, and PC4 it represented 31,20 , and $15 \%$, respectively. The second PC differed significantly according to dairy system (Table 4), as modern dairy systems with TMR had higher values than the other 3 farming systems (Figure 1).

Moving to the analyses of individual PTR-ToF-MS, Supplementary Table S4 (http://dx.doi.org/10.3168/ jds.2015-9803) shows that 57 out of 240 peaks were affected by the dairy system. Differences between the 2 traditional versus the 3 modern dairy systems were evident in only 2 of these peaks. In both cases, the cheeses from traditional farming systems had higher peaks than cheeses from modern systems. Of the traditional farms, those distributing compound feed in the mangers with automatic feeders displayed higher contents of 3 peaks (Supplementary Table S4). Of these, we identified methanol at $m / z 33.034$.

Within the modern dairy systems, the method of feedstuff distribution had a profound effect on the PTR-ToF-MS profile of model cheeses: those produced from farms using TMR were characterized by higher concentrations of 23 spectrometric peaks and lower concentrations of 12 peaks compared with farms where cows were fed conventionally (Supplementary Table S4; http://dx.doi.org/10.3168/jds.2015-9803). Of the 35 peaks affected by the use of TMR, 5 could be tentatively attributed to ethanal $(\mathrm{m} / z 45.033)$, acetic acid $(m / z$ 60.021), butan-1-ol $(m / z 75.080)$, and terpene fragments $(m / z 81.070)$ 
Among the dairy systems using TMR, those that added silages, as opposed to those adding just water to moisturize the ration and avoid demixing, presented significantly $(P<0.05)$ lower concentrations of 17 peaks (Supplementary Table S4; http://dx.doi.org/10.3168/ jds.2015-9803). In particular, hexan-1-ol, hexan-2-ol $(\mathrm{m} / z$ 85.101), ethyl butanoate, ethyl-2-methylpropanoate, hexanoic acid $(m / z 117.091)$, ethyl hexanoate, and octanoic acid $(m / z$ 145.123) were successfully identified. These compounds were mainly alcohols, acids, and esters. In the dairy systems without silage, we found higher concentrations of only one unknown peak at $m / z$ 65.018 (Supplementary Table S4; http://dx.doi. org/10.3168/jds.2015-9803).

\section{The Effect of Animal Characteristics}

The second and fourth $\mathrm{PC}$ exhibited a significant $(P$ $<0.001$ ) linear increase during lactation (Table 4). The patterns along the lactation obtained by plotting least squares means of the second and fourth PC for DIM are presented in Figure $2 \mathrm{~b}$ and $\mathrm{c}$, respectively.

Moving to individual peaks, we found just over half the PTR-ToF-MS peaks (139 out of 240) were affected by DIM (Supplementary Table S5; http://dx.doi. org/10.3168/jds.2015-9803). Among the 75 peaks showing linear increases throughout lactation, we identified methanethiol $(m / z 49.011)$, the alcohols butan-1-ol and butan-2-ol $(m / z 57.070 ; 75.080)$, the acids hexanoic acid $(m / z$ 99.081) and nonanoic acid $(m / z$ 159.138), and the esters ethyl butanoate, ethyl-2-methyl propanoate $(\mathrm{m} / \mathrm{z}$ 117.091), ethyl pentanoate, ethyl2-methylbutanoate, and ethyl-3-methylbutanoate $(\mathrm{m} / \mathrm{z}$ 131.107). In contrast, 34 peaks showed linear decreases during lactation, and of these we identified acetonitrile $(\mathrm{m} / z 42.034)$, ethanal $(\mathrm{m} / z 45.033)$, propan-2-one $(\mathrm{m} / z$ 59.049), 3-methylbutanal, 2-methylbutanal, heptanal, nonanal, and pentan-2-one $(\mathrm{m} / z$ 87.080).

The quadratic pattern was exhibited by 54 peaks, and of these ethanal $(\mathrm{m} / z$ 45.033), 2-methylbutanal, 3 -methylbutanal, heptanal, nonanal, penta-2-one $(\mathrm{m} / \mathrm{z}$ 69.033), hexan-1-ol, hexan-2-ol $(m / z$ 85.101), phenol $(m / z$ 95.049), hexanoic acid $(m / z$ 99.081), ethyl butanoate, ethyl-2-methyl propanoate $(\mathrm{m} / z$ 117.091), and 1-octen-3-one $(m / z 127.112)$ were identified. All these substances showed a tendency to increase during the initial stage of lactation, followed by a more stable content until midlactation and a rapid decrease thereafter.

Table 3. Highest correlation coefficients between the first five principal components and the volatile compounds tentatively attributed to specific spectrometric fragments of proton transfer reaction time of flight mass spectrometry

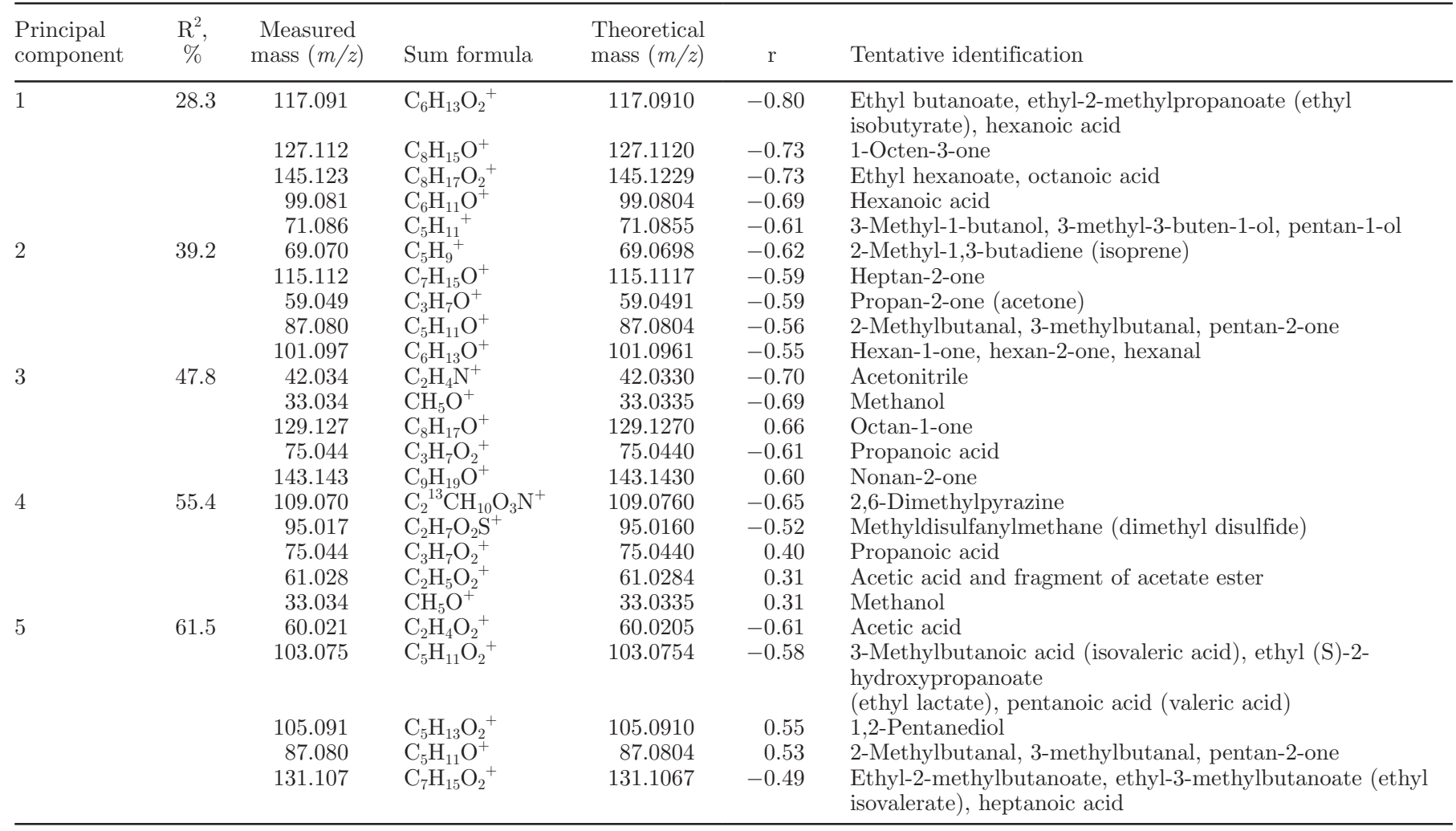


Table 4. F-values and significance from ANOVA on principal components for dairy systems, orthogonal contrasts between dairy systems, incidence of herd test date within dairy systems (HTD), DIM, parity, orthogonal contrasts between parity, milk yield, and vat

\begin{tabular}{|c|c|c|c|c|c|}
\hline \multirow[b]{2}{*}{ Trait } & \multicolumn{5}{|c|}{ Principal component } \\
\hline & 1 & 2 & 3 & 4 & 5 \\
\hline Dairy systems & 1.3 & $2.8^{*}$ & 0.7 & 1.2 & 0.5 \\
\hline Traditional versus modern farm & 0.3 & 1.6 & 0.7 & 2.6 & 0.8 \\
\hline Automatic feeder effect ${ }^{1}$ & 0.1 & 2.1 & 0.1 & 0.9 & 0.1 \\
\hline TMR effect ${ }^{2}$ & 0.7 & $8.9^{*}$ & 2.1 & 0.5 & 0.2 \\
\hline Silage effect ${ }^{3}$ & 3.2 & 0.5 & 0.1 & 1.4 & 0.8 \\
\hline $\mathrm{HTD}^{4} \%$ & 20 & 31 & 53 & 15 & 48 \\
\hline DIM & $4.1^{* * *}$ & $4.3^{* * *}$ & 0.6 & $3.1^{* *}$ & $3.2^{* *}$ \\
\hline Linear & $6.0^{*}$ & $10.0^{* *}$ & 2.2 & $10.0^{* *}$ & $5.7^{*}$ \\
\hline Quadratic & $5.6^{*}$ & 0.1 & 0.7 & 1.3 & 0.1 \\
\hline Cubic & 1.3 & 0.2 & 0.4 & 0.1 & 2.7 \\
\hline Parity & $4.5^{* *}$ & 2.3 & 1.3 & 0.6 & 1.8 \\
\hline 1 vs. $\geq 2$ & 0.7 & 2.1 & 0.1 & 0.4 & 1.8 \\
\hline 2 vs. $\geq 3$ & 0.1 & 2.1 & 0.9 & 0.1 & 0.5 \\
\hline 3 vs. $\geq 4$ & 0.3 & 3.6 & 0.3 & 0.3 & 0.5 \\
\hline Milk yield & 0.1 & 0.1 & $7.4^{* *}$ & 0.2 & 3.6 \\
\hline $\operatorname{Regr}^{5^{\circ}}$ & 0.046 & -0.042 & 0.061 & 0.027 & 0.024 \\
\hline Vat & 1.1 & 1.3 & 1.6 & 0.6 & 1.1 \\
\hline $\mathrm{RMSE}^{6}$ & 7.2 & 4.1 & 3.1 & 3.9 & 2.8 \\
\hline
\end{tabular}

${ }^{1}$ Contrast between traditional farms with compound feed administered in the mangers with hay vs. traditional farms with compound feed administered in the mangers through automatic feeders.

${ }^{2}$ Contrast between modern farms with hay and compound feed administered in the mangers vs. modern farms using TMR.

${ }^{3}$ Contrast between modern farms using TMR without silages vs. TMR with silages.

${ }^{4}$ Herd test day effect expressed as proportion of variance explained by herd test date calculated by dividing the corresponding variance component by the total variance.

${ }^{5}$ Regr $=$ linear regression with daily milk yield of PTR-ToF-MS spectrometric peaks expressed as natural logarithm of the parts per billion by volume.

${ }^{6} \mathrm{RMSE}=$ root mean square error

${ }^{*} P<0.05 ;{ }^{* *} P<0.01 ;{ }^{* * *} P<0.001$.

Finally, 12 masses showed more complex trends during lactation (cubic pattern), and among these we tentatively identified 3-methyl-1-butanol, 3-methyl3-buten-1-ol, pentan-1-ol ( $m / z$ 71.086), and butan-2,3dione $(m / z$ 87.044).

Parity of cows also affected the headspace PTR-ToFMS profile measured on individual model cheeses. In particular, it affected 22 out of 240 individual peaks compared with the previously examined sources of variation (dairy system and DIM). Cheeses from primiparous cows had higher concentrations of 7 PTRToF-MS peaks than cheeses from multiparous cows (Supplementary Table S6; http://dx.doi.org/10.3168/ jds.2015-9803). Four of these peaks, as well as 6 peaks not affected by cows at first parity, were also different in mature cows (third parity) compared with older cows ( 4 or more parities). Of these, $m / z 49.011$ was attributed to methanethiol. Moreover, we found that the headspace of cheeses from second-lactation cows have higher quantities of 3 masses than cheeses from cows with 3 or more calvings (Supplementary Table S6).
Cow productivity (daily milk yield corrected for DIM and parity, as well as dairy system and herd) also affected the volatile fingerprint of individual model cheeses. The third PC increased with the increase in daily milk yield (Table 4). The concentrations of 23 peaks increased with increasing milk yield, whereas 8 peaks decreased (Supplementary Table S7; http:// dx.doi.org/10.3168/jds.2015-9803). Among the masses that increased, we identified $m / z 85.065$ as pentanoic acid; $m / z 86.072$ as pentanal; $m / z 87.080$ as 2 -methylbutanal, 3-methylbutanal, and pentan-2-one; $\mathrm{m} / \mathrm{z}$ 101.097 as hexan-1-one, hexan-2-one, and hexanal; $\mathrm{m} / z$ 115.112 as heptan-2-one; $m / z 129.127$ as octan-1-one, and $m / z 143.143$ as nonan-2-one (Supplementary Table S7).

\section{DISCUSSION}

\section{PTR-ToF-MS Data}

The PTR-ToF-MS output was composed of hundreds of reciprocally related masses and the absence of a pre- 
separation procedure results in different compounds or fragments being retrieved as the same peak (Aprea et al., 2007; Biasioli et al., 2011; Cappellin et al., 2011). An efficient way of analyzing this kind of data is multivariate analysis (e.g., principal component) carried out in 2 steps: (1) data compression to reduce the size of the data set without significant loss of information, and (2) identification of peaks that could help biological interpretation of the available information. The extracted PC can be used to investigate relationships with the original variables (peaks or cheese VOC), and the values (scores) of these factors can be treated as a new phenotype for further analysis. These synthetic indicators of VOC profiles were used to study dairy systems and sources of variation in individual dairy cows. The PC were positively and negatively related to groups of VOC, in many cases with same catabolic pathway, chemical family, or odor. Nevertheless, it was sometimes difficult to interpret the exhibited trends especially when the masses most related to the common components were unknown. In agreement with results regarding the cheesemaking properties of milk (Cipolat-Gotet et al., 2013, 2015) obtained from individual model cheese manufacture, we found that the effect of vat was not significant for any of the PC extracted, confirming the good reproducibility of the technique when used to study cheese quality traits (Table 4).

\section{The Effects of Dairy Systems and Herds Within the Dairy System}

Within farming systems, the composition of the basal diet is important for establishing the nutritional and sensory proprieties of milk and cheese (Couvreur et al., 2007; Romanzin et al., 2013; Bovolenta et al., 2014). The differences found in the VOC of model cheeses from the 5 different dairy systems are clearly summarized by PC2 (Figure 1), which reflects milk characteristics and also the production conditions of the dairy farms. No significant variations in cheese gross composition according to farming system were observed, which means that the differences in VOC cannot be directly linked to cheese gross composition.

In the current study we found no differences between the 2 traditional versus the 3 modern dairy systems when the PC were analyzed (Table 4). The use of TMR in the modern farming systems resulted in greater differences in the cheese VOC profiles: the differences between the modern dairy systems with hay and compound feed administered separately (with a greater proportion of forages in the diets) and the modern systems with TMR (using more concentrates) were linked to the esters, acids, and terpenes. It is well known that TMR optimizes rumen function and improves cow production efficiency in terms of DMI and daily milk yield

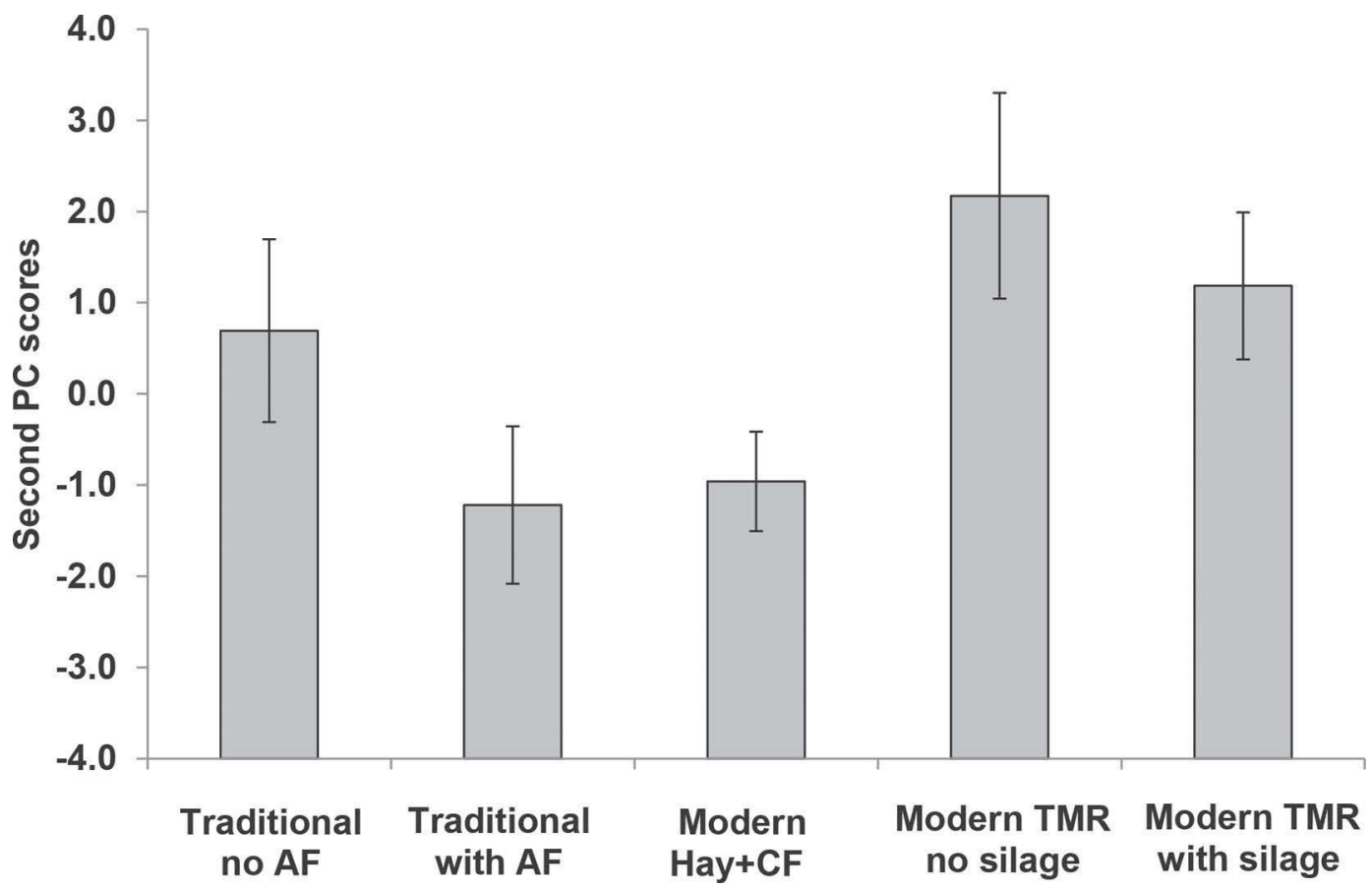

Figure 1. Least squares means $( \pm \mathrm{SE})$ of the extracted second principal component $(\mathrm{PC})$ scores for different dairy systems. $\mathrm{AF}=$ automatic feeders at mangers to control individually concentrate distribution of tied cows; $\mathrm{CF}=$ compound feed distributed at mangers; no silage $=$ water is added in the mixer wagon to favor mixing. Orthogonal contrast between modern farms with hay and compound feed administered in the mangers vs. modern farms using total mixed rations was statistically different $(P<0.05)$. 

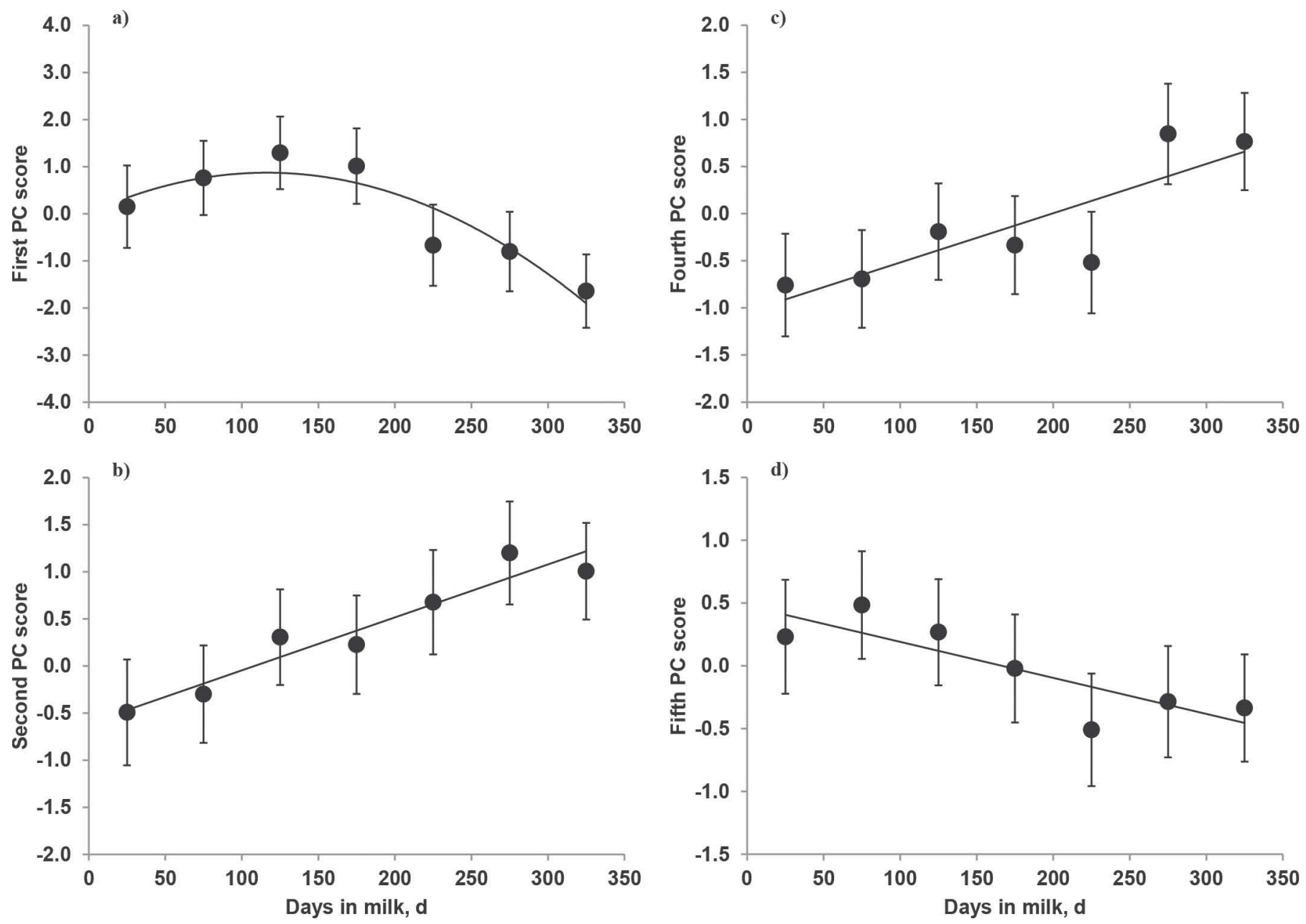

Figure 2. Least squares means $( \pm \mathrm{SE})$ of the extracted first (a), second (b), fourth (c), and fifth (d) principal components (PC) that exhibited significant $(P<0.01)$ patterns along lactation.

(Tafaj et al., 2007; McBeth et al., 2013). Caccamo et al. (2012) examined the effect of TMR on production and milk composition traits and found that the starch content of the ration was the most important element related to the increase in milk yield, fat, and protein contents over the cows' entire lactation.

Among the masses most positively correlated with PC2 (Table 3), we found $m / z 117.091$ (tentatively attributed to ethyl butanoate and ethyl-2-methylpropanoate) and $m / z 145.123$ (ethyl hexanoate). These compounds derive from the condensation between FFA and alcohols (Curioni and Bosset, 2002) and are responsible for fruity-floral notes in cheese flavor (Frank et al., 2004; Cornu et al., 2009; Sympoura et al., 2009). Other VOC significantly affected by TMR were terpenes, which can be transferred from the plant to the milk and have been listed as cheese odorants with a fresh, herbaceous odor (Viallon et al., 2000; Curioni and Bosset, 2002; Carpino et al., 2004). The terpenes ingested by cows have been suspected of having an effect on rumen microflora. In particular, protein degradation and VFA production may, due to nutrient flow out of the rumen, result in milk and cheese compositional changes and, consequently, variations in sensory proprieties (Noni and Battelli, 2008; Tornambé et al., 2008).

In our study, maize silage was the main component of the forage proportion of TMR in the modern dairy systems using silages. Several studies have shown that the use of maize silage versus grass generally leads to cheeses that are less valued because their flavor is less developed (Coulon et al., 2004; Hurtaud et al., 2004; Martin et al., 2004). In contrast, no significant differences were reported between cheeses made from milk produced by cows fed with hay and those from cows fed with grass silage (Verdier-Metz et al., 2005). Previous studies reported lower concentrations of alcohols from $\mathrm{C}_{2}$ to $\mathrm{C}_{6}$, such as hexan-1-ol and hexan-2-ol $(\mathrm{m} / \mathrm{z}$ $85.101)$, in the VOC profile of milk from cows fed 
diets based on hay rather than those including maize silage (Kalač, 2011). Acids originating from plants or produced during ensiling and alcohols formed in silage can produce various esters, such as ethyl butanoate and ethyl-2-methylpropanoate; in our study they were related to $\mathrm{PC} 2$ and statistically significantly $(P<$ $0.05)$ influenced by the use of silage $(m / z 117.091)$. We found other esters and acids correlated with PC2 and more significantly $(P<0.05)$ affected by the use of silage, such as ethyl hexanoate and octanoic acid $(\mathrm{m} / \mathrm{z}$ 145.123).

The amounts of concentrates in the cow diets may increase milk fat content, de novo FA, and total SFA (Borreani et al., 2013; Romanzin et al., 2013). The level of FA oxidation may vary depending on the animal's diet; for instance, milk from a diet based on hay and concentrate had low antioxidant potential (Agabriel et al., 2007; Calderón et al., 2007). The lipolysis system affected by nutritional and physiological factors plays an important role in the development of flavor and rancidity in dairy products (Chilliard et al., 2003). Furthermore, in the present study, the lower volatile compound contents in cheeses from a corn silage-based diet could result from lower postmilking lipolysis activity, as previously noted by Ferlay et al. (2006).

\section{The Effect of Lactation Stage}

The influence of lactation stage on the cheese VOC fingerprint appears to be by far the most important of the different sources of variation found in this experiment. Indeed, 4 PC that together account for $52.9 \%$ of the total original variance were affected by lactation stage (Table 4). Principal component 1 and PC5, which together account for $34.4 \%$ of the total information, decreased across lactation (Figure $2 \mathrm{a}$ and $\mathrm{d}$, respectively). An opposite trend was shown by PC2 and PC4, which linearly increased during lactation (Figure 2b and $c$, respectively). These variables summarize the VOC profile influenced by DIM without losing much information, because most of the peaks (75/139) also significantly increased during lactation (Supplementary Table S5). This result is in agreement with Bergamaschi et al. (2015), who studied the VOC profiles analyzed by SPME/GC-MS of a subset of samples from the same model cheeses discussed here. Our results concur with previous studies reporting a major influence of stage of lactation on sensory traits, with cheeses from latelactation milk having a less pleasant odor (Coulon et al., 2004).

The ANOVA results show the compounds more significantly $(P<0.01)$ affected by stage of lactation to be alcohols, acids, esters, aldehydes, and ketones. The higher concentration in cheese from late-lactation milk of peaks and fragments associated with alcohols, such as butan-1-ol and butan-2-ol $(\mathrm{m} / z 57.070$ and 75.080, respectively), is in agreement with previous findings regarding the flavor of raw milk and Fontina cheese (Carbonell et al., 2002; Berard et al., 2007). Primary alcohols, such as butan-1-ol, generally originate from the corresponding aldehydes, whereas butan-2-ol may be formed by the action of the starter bacteria on butan-2,3-dione to butan-2,3-diol and subsequent transformation to butan-2-ol as a consequence of nonstarter lactic acid bacteria activity during cheese ripening (Berard et al., 2007). Hexanoic acid $(\mathrm{m} / z$ 99.081) also increased during lactation. This acid is generally produced from lipolysis of milk fat and has also been identified as a characteristic flavor component of Grana Padano, Parmigiano-Reggiano, and Roncal cheeses (Curioni and Bosset, 2002; Bellesia et al., 2003).

A possible explanation for these positive trends in VOC found in model cheeses could be related to the well-known effect of DIM on the increase in milk fat and protein content during lactation (excepting the initial decrease) and on cheese gross composition (Stoop et al., 2009; Perna et al., 2014). Nevertheless, it should be pointed out that only about half of the peaks affected by DIM showed an increase during lactation, and the majority of them showed much greater variations than those observed for milk and cheese composition (taking into account that the data are expressed as logarithm of the concentration). Moreover, many masses showed an opposite decreasing trend so that the effect of lactation stage on the PTR-ToF-MS profile is probably more complex, involving drivers other than milk and cheese composition. One possible explanation rely also on the lower coagulum drying capacity or syneresis and the higher soluble protein content at the end $(>200$ d) of lactation (Martin and Coulon, 1995a; Ostersen et al., 1997; Bittante et al., 2015). The effect of lactation stage on VOC could also be related to higher SCC in late lactation, sometimes accompanied by elevated levels of milk enzymes (e.g., plasmin, cathepsin), which may increase protein degradation. A small amount of protein degradation, which does not affect the cheese gross composition, can originate from a relatively large increase in volatile compounds (Marino et al., 2005; Mazal et al., 2007; Hand et al., 2012). Moreover, the cheeses produced with milk from animals in late lactation are also frequently described as high in moisture and with faster proteolysis and lipolysis, which influence the texture and flavor of cheese (Coulon et al., 2004).

In addition, the energy status of the cows changes throughout lactation and significantly contributes to variations in milk fat composition because it alters different FA pathways, such as de novo synthesis in the 
mammary gland and biohydrogenation in the rumen (Stoop et al., 2009). Furthermore, VOC concentration could be affected by hormonal balance during gestation, because in late lactation fetal growth causes a restriction in food intake, the mobilization of body fat reserves, a reduction in milk production, and sometimes depletion of the dairy milk components (Ostersen et al., 1997).

Other VOC significantly $(P<0.001)$ influenced by DIM include ethanal $(m / z 45.033)$, which may be produced through lactic acid bacteria activity from glucose via pyruvate and imparts green apple flavor notes to dairy products such as yogurt and cheese (Curioni and Bosset, 2002; Soukoulis et al., 2010); 2-methylbutanal, 3-methylbutanal $(\mathrm{m} / \mathrm{z} 87.080)$, hexanal, and nonanal $(\mathrm{m} / z$ 69.033), which may result from lipid oxidation or degradation of AA (Strecker reaction) and are often associated with green grass and herbaceous aromas in cheese (Curioni and Bosset, 2002; Cornu et al., 2009; Thomsen et al., 2012); and carbonyl compounds propan-2-one $(m / z 59.049)$ and pentan-2-one $(m / z 87.080)$, which are probably produced by decarboxylation of the respective FA by lactic acid bacteria (Curioni and Bosset, 2002).

Reductions in these compounds throughout lactation may be linked to elements that were not measured in our study, such as initial microbial composition and their enzymatic activity. Milk and cheese protein can biologically include active peptides, which variously inhibited the amino and endo-peptidase of lactic acid bacteria (Smacchi and Gobbetti, 1998). The activity of these peptidases is very important during cheese ripening because they supply free AA that may be major precursors of specific flavor molecules, such as various alcohols, aldehydes, acids, esters, and sulfur compounds (Smit et al., 2005; Perna et al., 2014).

\section{The Effect of Parity}

Previous studies have demonstrated the importance of parity on milk composition (Kroeker et al., 1985), milk coagulation proprieties (Bittante et al., 2012), and nutrient recovery or loss in the whey of model cheeses from individual bovine and buffalo milk (Cipolat-Gotet et al., 2013, 2015). More recently, the effect of number of lactations on the VOC of a subdata set of the model cheeses considered in the current work has also been investigated (Bergamaschi et al., 2015), but to our knowledge no published paper deals with the sensory properties of cheeses.

The peak $m / z$ 49.011, attributed to methanethiol, known for its sulfurous note in the cheese aroma of different varieties, increased with parity (Curioni and Bosset, 2002; Bellesia et al., 2003; Cornu et al., 2009).
The effect of parity on cheese VOC was not related to model cheese gross composition. Nevertheless, as previously reported (Erdem et al., 2010; Sánchez-Macías et al., 2013), the increase with parity of SCC (data not shown) may explain in part the VOC variations. Indeed, as already discussed above, the more intense proteolysis during ripening in the case of high SCC observed by Coulon et al. (2004) and Marino et al. (2005) may be responsible for the increasing trend of some volatile compounds. Moreover, higher SCC are usually associated with modification in other chemical compounds in milk, such as soluble proteins, which modify the cheesemaking ability of milk (Mazal et al., 2007; Erdem et al., 2010; Sánchez-Macías et al., 2013). Cipolat-Gotet et al. (2013) studied individual sources of variation on protein recovery of milk in curd and reported a decrease in the case of older cows.

Among the volatile compounds more significantly influenced $(P<0.05)$ by parity, we also found acids and esters. These VOC, in particular ethyl hexanoate and octanoic acid ( $m / z$ 145.123), may originate from AA or FA catabolism (McSweeney and Sousa, 2000). Acids and esters have also been reported to have an important role in the flavor of Parmigiano-Reggiano (Bellesia et al., 2003), Camembert (Curioni and Bosset, 2002), and Cantal cheese (Cornu et al., 2009). Their variation according to lactation (higher in third vs. fourth or more parities) could be linked, at least in part, to milk composition.

\section{The Effect of Milk Yield}

Many studies have investigated the effect of diet, stage of lactation, and farming system on milk and cheese characteristics (Coulon et al., 2004; Ferlay et al., 2006; Borreani et al., 2013); but, to our knowledge, very few authors have studied the relationships between cheese VOC and daily milk yield independently from the other effects studied in this experiment. Our findings indicate that variations in milk yield within herd, parity, and DIM influence the VOC profile of model cheeses, in agreement with previous work in this area using other analytical techniques (Bergamaschi et al., 2015).

The third PC (Table 3) was positively related to volatile compounds belonging to 2 ketones, octan-1-one $(\mathrm{m} / z 129.127)$, and nonan-2-one $(\mathrm{m} / z \mathrm{143.143)}$, and negatively with acetonitrile $(\mathrm{m} / z$ 42.034), methanol $(\mathrm{m} / z$ $33.034)$, and propanoic acid $(m / z 75.044)$. The masses more significantly $(P<0.05)$ affected by milk yield corresponded to VOC belonging to different chemical families: acids, aldehydes, and ketones. Among these, we found some peaks with a lower correlation with PC3, such as hexan-1-one, hexan-2-one, and hexanal $(\mathrm{m} / \mathrm{z}$ 
101.097). In contrast, propanoic acid $(m / z$ 75.044) had higher correlation coefficients and characterized PC3 (Table 3). It is interesting to note that some peaks, and some PC, were significantly affected by 2 or more sources of variations: for example, 2-methylbutanal, 3-methylbutanal, and penta-2-one $(m / z$ 87.080) were affected by both DIM and milk yield. Moreover, ethyl hexanoate and octanoic acid $(m / z 145.123)$ differed significantly according to DIM, parity, and dairy systems. The statistical model used in our experiment was supposed to segregate all these associated factors but some overlap cannot be excluded.

\section{CONCLUSIONS}

The results of the present research show PTR-ToFMS to be a powerful technique for characterizing the VOC of cheese, and, because of its simplicity of sample preparation and high-throughput can be applied also on a large number of samples. As this technique detects a very high number of peaks, a multivariate analysis, such as principal components analysis, is a useful method for compressing information in a few traits to be used as new phenotypes. These new synthetic indicators summarize the main trends of groups of volatile compounds, which could be related to the same catabolic pathways, chemical families or flavors. The combination of 2 high-throughput techniques, such as PTR-ToF-MS and the model cheesemaking procedure, proved to be a powerful instrument for investigating the relationships between animal characteristics, farm characteristics, milk processing, and cheese quality. This approach allowed the investigation of the effects of dairy system and individual animal characteristics on cheese volatile organic profiles at the individual level. In conclusion, high-throughput methodologies, such as model cheese production and rapid volatile compound profiling by PTR-ToF-MS, open new avenues for the investigation of the effects of farming systems and individual animal traits on the final quality of cheese, and new directions in the genetic improvement of dairy species.

\section{ACKNOWLEDGMENTS}

This work was financially supported by Trento Province (Italy). The authors are grateful to the Breeders Federation of Trento Province (Italy) for supplying the information on cows, the producers involved in the project for their availability, Ilario Bazzoli (Breeders Federation of Trento, Trento, Italy) for organizing the herd sampling, Brian Farneti (Department of Agricultural Sciences, University of Bologna, Italy) for initial data analysis and Elisa Forato (DAFNAE Department, University of Padova, Legnaro, Italy) for the PTRToF-MS analysis.

\section{REFERENCES}

Agabriel, C., A. Cornu, C. Journal, C. Sibra, P. Grolier, and B. Martin. 2007. Tanker milk variability according to farm feeding practices: vitamins $\mathrm{A}$ and E, carotenoids, color, and terpenoids. J. Dairy Sci. 90:4884-4896.

Ali, A. K. A., and G. E. Shook. 1980. An optimum transformation for somatic cell concentration in milk. J. Dairy Sci. 63:487-490.

Aprea, E., F. Biasioli, F. Gasperi, D. Motta, F. Marini, and T. D. Märk. 2007. Assessment of Trentingrana cheese ageing by proton transfer reaction-mass spectrometry and chemometrics. Int. Dairy J. 17:226-234.

Bellesia, F., A. Pinetti, U. Pagnoni, R. Rinaldi, C. Zucchi, L. Caglioti, and G. Palyi. 2003. Volatile components of Grana ParmigianoReggiano type hard cheese. Food Chem. 83:55-61.

Berard, J., F. Bianchi, M. Careri, A. Chatel, A. Mangia, and M. Musci. 2007. Characterization of the volatile fraction and of free fatty acids of "Fontina Valle d'Aosta," a protected designation of origin Italian cheese. Food Chem. 105:293-300.

Bergamaschi, M., E. Aprea, E. Betta, F. Biasioli, C. Cipolat-Gotet, A. Cecchinato, G. Bittante, and F. Gasperi. 2015. Effects of the dairy system, herd and individual cow characteristics on the volatile organic compound profile of ripened model cheeses. J. Dairy Sci. 98:2183-2196.

Biasioli, F., F. Gasperi, E. Aprea, I. Endrizzi, V. Framondino, F. Marini, D. Mott, and T. D. Märk. 2006. Correlation of PTR-MS spectral fingerprints with sensory characterisation of flavor and odor profile of "Trentingrana" cheese. Food Qual. Prefer. 17:63-75.

Biasioli, F., F. Gasperi, C. Yeretzian, and T. D. Märk. 2011. PTR-MS monitoring of VOCs and BVOCs in food science and technology. TrAC Trends Anal. Chem. 30:968-977.

Bittante, G., A. Cecchinato, N. Cologna, M. Penasa, F. Tiezzi, and M. De Marchi. 2011a. Factors affecting the incidence of first-quality wheels of Trentingrana cheese. J. Dairy Sci. 94:3700-3707.

Bittante, G., C. Cipolat-Gotet, and A. Cecchinato. 2013. Genetic parameters of different measures of cheese yield and milk nutrient recovery from an individual model cheese-manufacturing process. J. Dairy Sci. 96:7966-7979.

Bittante, G., C. Cipolat-Gotet, F. Malchiodi, E. Sturaro, F. Tagliapietra, S. Schiavon, and A. Cecchinato. 2015. Effect of dairy farming system, herd, season, parity, and days in milk on modeling of coagulation, curd firming and syneresis of bovine milk. J. Dairy Sci. 98:2759-2774.

Bittante, G., N. Cologna, A. Cecchinato, M. De Marchi, M. Penasa, F. Tiezzi, I. Endrizzi, and F. Gasperi. 2011b. Monitoring of sensory attributes used in the quality payment system of Trentingrana cheese. J. Dairy Sci. 94:5699-5709.

Bittante, G., A. Ferragina, C. Cipolat-Gotet, and A. Cecchinato. 2014. Comparison between genetic parameters of cheese yield and nutrient recovery or whey loss traits measured from individual model cheese-making methods or predicted from unprocessed bovine milk samples using fourier-transform infrared spectroscopy. J. Dairy Sci. 97:6560-6572.

Bittante, G., M. Penasa, and A. Cecchinato. 2012. Invited review: Genetics and modeling of milk coagulation properties. J. Dairy Sci. 95:6843-6870.

Borreani, G., M. Coppa, A. Ravello-Chion, L. Comino, D. Giaccone, A. Ferlay, and E. Tabacco. 2013. Effect of different feeding strategies in intensive dairy farming systems on milk fatty acid profiles, and implications on feeding costs in Italy. J. Dairy Sci. 96:6840-6855.

Bovolenta, S., A. Romanzin, M. Corazzin, M. Spanghero, E. Aprea, F. Gasperi, and E. Piasentier. 2014. Volatile compounds and sensory properties of Montasio cheese made from the milk of Simmental cows grazing on alpine pastures. J. Dairy Sci. 97:7373-7385. 
Caccamo, M., R. F. Veerkamp, G. Licitra, R. Petriglieri, F. La Terra, A. Pozzebon, and J. D. Ferguson. 2012. Association of total-mixed ration chemical composition with milk, fat, and protein yield lactation curves at individual level. J. Dairy Sci. 95:6171-6183.

Calderón, F., B. Chauveau-Duriot, P. Pradel, B. Martin, B. Graulet, M. Doreau, and P. Nozière. 2007. Variations in carotenoids, vitamins A and E, and color in cow's plasma and milk following a shift from hay diet to diets containing increasing levels of carotenoids and vitamin E. J. Dairy Sci. 90:5651-5664.

Cappellin, L., E. Aprea, P. Granitto, R. Wehrens, C. Soukoulis, R. Viola, T. D. Märk, F. Gasperi, and F. Biasioli. 2012a. Linking GC-MS and PTR-TOF-MS fingerprints of food samples. Chemom. Intell. Lab. Syst. 118:301-307.

Cappellin, L., F. Biasioli, E. Schuhfried, C. Soukoulis, T. D. Märk, and F. Gasperi. 2011. Extending the dynamic range of proton transfer reaction time of flight mass spectrometers by a novel dead time correction. Rapid Commun. Mass Spectrom. 25:179-183.

Cappellin, L., T. Karl, M. Probst, O. Ismailova, P. M. Winkler, C. Soukoulis, E. Aprea, T. D. Märk, F. Gasperi, and F. Biasioli. $2012 \mathrm{~b}$. On quantitative determination of volatile organic compound concentrations using proton transfer reaction time of flight mass spectrometry. Environ. Sci. Technol. 46:2283-2290.

Carbonell, M., M. Nunez, and E. Fernandez-Garcıa. 2002. Seasona variation of volatile compounds in ewes raw milk La Serena cheese. Lait 82:699-711.

Carpino, S., S. Mallia, S. La Terra, C. Melilli, G. Licitra, T. E. Acree, D. M. Barbano, and P. J. Van Soest. 2004. Composition and aroma compounds of Ragusano cheese: Native pasture and total mixed rations. J. Dairy Sci. 87:816-830.

Cecchinato, A., A. Albera, C. Cipolat-Gotet, A. Ferragina, and G. Bittante. 2015. Genetic parameters of cheese yield and curd nutrient recovery traits predicted using Fourier-transform infrared spectroscopy (FTIR) of samples collected during milk recording on Holstein, Brown Swiss and Simmental dairy cows. J. Dairy Sci. 98:4914-4927.

Cecchinato, A., C. Cipolat-Gotet, J. Casellas, M. Penasa, A. Rossoni, and G. Bittante. 2013. Genetic analysis of rennet coagulation time, curd-firming rate, and curd firmness assessed on an extended testing period using mechanical and near-infrared instruments. J. Dairy Sci. 96:50-62.

Childs, J. L., and M. A. Drake. 2009. Consumer perception of fat reduction in cheeses. J. Sens. Stud. 24:902-921.

Chilliard, Y., A. Ferlay, J. Rouel, and G. Lamberet. 2003. A review of nutritional and physiological factors affecting goat milk lipid synthesis and lipolysis. J. Dairy Sci. 86:1751-1770.

Cipolat-Gotet, C., G. Bittante, and A. Cecchinato. 2015. Phenotypic analysis of cheese yields and nutrient recoveries in the curd of buffalo milk, as measured with an individual model cheese-manufacturing process. J. Dairy Sci. 98:633-645.

Cipolat-Gotet, C., A. Cecchinato, M. De Marchi, and G. Bittante. 2013. Factors affecting variation of different measures of cheese yield and milk nutrients recovery from an individual model cheesemanufacturing process. J. Dairy Sci. 96:7952-7965.

Cipolat-Gotet, C.. A. Cecchinato, M. De Marchi, M. Penasa, and G. Bittante. 2012. Comparison between mechanical and near-infrared methods for assessing coagulation properties of bovine milk. J. Dairy Sci. 95:6806-6819.

Cornu, A., N. Rabiau, N. Kondjoyan, I. Verdier-Metz, P. Pradel, P. Tournayre, J. L. Berdagué, and B. Martin. 2009. Odour-active compound profiles in Cantal-type cheese: Effect of cow diet, milk pasteurization and cheese ripening. Int. Dairy J. 19:588-594.

Coulon, J. B., A. Delacroix-Buchet, B. Martin, and A. Pirisi. 2004. Relationships between ruminant management and sensory characteristics of cheeses: A review. Lait 84:221-241.

Couvreur, S., C. Hurtaud, P. G. Marnet, P. Faverdin, and J. L. Peyraud. 2007. Composition of milk fat from cows selected for milk fat globule size and offered either fresh pasture or a corn silage-based diet. J. Dairy Sci. 90:392-403.

Curioni, P. M. G., and J. O. Bosset. 2002. Key odorants in various cheese types as determined by gas chromatography-olfactometry. Int. Dairy J. 12:959-984.
Drake, S. L., P. D. Gerard, and M. A. Drake. 2008. Consumer preferences for mild Cheddar cheese flavors. J. Food Sci. 73:S449-S455.

Erdem, H., S. Atasever, and E. Kul. 2010. Relationships of milk ability traits to udder characteristics, milk yield and somatic cell count in Jersey cows. J. Appl. Anim. Res. 37:43-47.

Fabris, A., F. Biasioli, P. M. Granitto, E. Aprea, L. Cappellin, E. Schuhfried, C. Soukoulis, T. D. Märk, F. Gasperi, and I. Endrizzi. 2010. PTR-TOF-MS and data-mining methods for rapid characterization of agro-industrial samples: Influence of milk storage conditions on the volatile compounds profile of Trentingrana cheese. J. Mass Spectrom. 45:1065-1074.

Ferlay, A., B. Martin, Ph. Pradel, J. B. Coulon, and Y. Chilliard. 2006 Influence of grass-based diets on milk fatty acid composition and milk lipolytic system in Tarentaise and Montbeliarde cow breeds. J. Dairy Sci. 89:4026-4041.

Ferragina, A., C. Cipolat-Gotet, A. Cecchinato, and G. Bittante. 2013. The use of Fourier-transform infrared spectroscopy to predict cheese yield and nutrient recovery or whey loss traits from unprocessed bovine milk samples. J. Dairy Sci. 96:7980-7990.

Ferragina, A., G. de los Campos, A. Vazquez, A. Cecchinato, and G. Bittante. 2015. Bayesian regression models outperform partial least squares methods for predicting milk components and technological properties using infrared spectra data. J. Dairy Sci. 98:8133-8152.

Frank, D. C., C. M. Owen, and J. Patterson. 2004. Solid phase microextraction (SPME) combined with gas-chromatography and olfactometry-mass spectrometry for characterization of cheese aroma compounds. Lebenson. Wiss. Technol. 37:139-154.

Galle, S. A., A. Koot, C. Soukoulis, L. Cappellin, F. Biasioli, M Alewijn, and S. M. van Ruth. 2011. Typicality and geographical origin markers of protected origin cheese from the Netherlands revealed by PTR-MS. J. Agric. Food Chem. 59:2554-2563.

Hand, K. J., A. Godkin, and D. F. Kelton. 2012. Milk production and somatic cell counts: A cow-level analysis. J. Dairy Sci. 95:13581362

Hurtaud, C., B. Martin, J. B. Coulon, and J. L. Peyraud. 2004. Dairy Cows Feeding Changes the Biochemical Compositions and the Sensory Proprieties of The Dairy Products, Butter and Cheese. International Society for Animal Hygiene, Saint-Malo, France.

Kalač, P. 2011. The effects of silage feeding on some sensory and health attributes of cow's milk: A review. Food Chem. 125:307-317.

Kroeker, E. M., K. F. Ng-Kwai-Hang, J. F. Hayes, and J. E. Moxley. 1985. Effects of environmental factors and milk protein polymorphism on composition of casein fraction in bovine milk. J. Dairy Sci. 68:1752-1757.

Lindinger, W., A. Hansel, and A. Jordan. 1998. On-line monitoring of volatile organic compounds at ppt $_{\mathrm{y}}$ levels by means of proton transfer reaction-mass spectrometry (PTR-MS) medical applications, food control and environmental research. Int. J. Mass Spectrom. Ion Process. 173:191-241.

Marino, R., T. Considine, A. Sevi, P. L. H. McSweeney, and A. L. Kelly. 2005. Contribution of proteolytic activity associated with somatic cells in milk to cheese ripening. Int. Dairy J. 15:1026-1033.

Martin, B., and J. B. Coulon. 1995a. Milk production and cheese characteristics. I. Influence of milk production conditions on coagulability of bulk milk. Lait 75:61-80.

Martin, B., and J. B. Coulon. 1995b. Facteurs de production du lait et caractéristiques des fromages. II. Influence des caractéristiques des laits de troupeaux et des pratiques fromagères sur les caractéristiques du reblochon de Savoie fermier. Lait 75:133-149.

Martin, B., I. Verdier-Metz, S. Hulin, A. Ferlay, P. Pradel, and J. B. Coulon. 2004. Combined influence of cow diet and pasteurization of the milk on sensory properties of French PDO Cantal cheese. Page 5 in 6th International Meeting on Mountain Cheese, Ragusa, Italy

Mazal, G., P. C. B. Vianna, M. V. Santos, and M. L. Gigante. 2007. Effect of somatic cell count on Prato cheese composition. J. Dairy Sci. 90:630-636.

McBeth, L. R., N. R. St-Pierre, D. E. Shoemaker, and W. P. Weiss. 2013. Effects of transient changes in silage dry matter concentration on lactating dairy cows. J. Dairy Sci. 96:3924-3935. 
McSweeney, P. L. H., and M. J. Sousa. 2000. Biochemical pathways for the production of flavor compounds in cheeses during ripening: A review. Lait 80:293-324.

Noni, I. D., and G. Battelli. 2008. Terpenes and fatty acid profiles of milk fat and "Bitto" cheese as affected by transhumance of cows on different mountain pastures. Food Chem. 109:299-309.

Ostersen, S., J. Foldager, and J. E. Hermansen. 1997. Effects of stage of lactation, milk protein and body condition at calving on protein composition and renneting properties of bovine milk. J. Dairy Res. 64:207-219.

Perna, A., A. Simonetti, I. Intaglietta, and E. Gambacorta. 2014. Effects of genetic type, stage of lactation, and ripening time on Caciocavallo cheese proteolysis. J. Dairy Sci. 97:1909-1917.

Rodriguez-Saona, L. E., N. Koca, W. J. Harper, and V. B. Alvarez. 2006. Rapid determination of Swiss cheese composition by Fourier transform infrared/attenuated total reflectance spectroscopy. J. Dairy Sci. 89:1407-1412.

Romanzin, A., M. Corazzin, E. Piasentier, and S. Bovolenta. 2013. Effect of rearing system (mountain pasture vs. indoor) of Simmental cows on milk composition and Montasio cheese characteristics. J. Dairy Res. 80:390-399.

Sánchez-Macías, D., A. Morales-delaNuez, A. Torres, L. E. HernándezCastellano, R. Jiménez-Flores, N. Castro, and A. Argüello. 2013. Effects of addition of somatic cells to caprine milk on cheese quality. Int. Dairy J. 29:61-67.

Smacchi, E., and E. Gobbetti. 1998. Peptides from several Italian cheeses inhibitory to proteolytic enzymes of lactic acid bacteria, Pseudomonas fluorescens ATCC 948 and to the angiotensin I-converting enzyme. Enzyme Microb. Technol. 22:687-694.

Smit, G., B. A. Smit, and W. J. M. Engels. 2005. Flavor formation by lactic acid bacteria and biochemical flavor profiling of cheese products. FEMS Microbiol. Rev. 29:591-610.

Soukoulis, C., E. Aprea, F. Biasioli, L. Cappellin, E. Schuhfried, T. D. Märk, and F. Gasperi. 2010. Proton transfer reaction time-of-flight mass spectrometry monitoring of the evolution of volatile compounds during lactic acid fermentation of milk. Rapid Commun. Mass Spectrom. 24:2127-3134.

Stoop, W. M., H. Bovenhuis, J. M. L. Heck, and J. A. M. van Arendonk. 2009. Effect of lactation stage and energy status on milk fat composition of Holstein-Friesian cows. J. Dairy Sci. 92:1469-1478.

Sturaro, E., E. Marchiori, G. Cocca, M. Penasa, M. Ramanzin, and G. Bittante. 2013. Dairy systems in mountainous areas: Farm animal biodiversity, milk production and destination, and land use. Livest. Sci. 158:157-168.

Sympoura, F., A. Cornu, P. Tournayre, T. Massouras, J. L. Berdagué, and B. Martin. 2009. Odor compounds in cheese made from the milk of cows supplemented with extruded linseed and $\alpha$-tocopherol. J. Dairy Sci. 92:3040-3048.

Tafaj, M., Q. Zebeli, Ch. Baes, H. Steingass, and W. Drochner. 2007. A meta-analysis examining effects of particle size of total mixed rations on intake, rumen digestion and milk production in highyielding dairy cows in early lactation. Anim. Feed Sci. Technol. 138:137-161.

Thomsen, M., C. Martin, F. Mercier, P. Tournayre, J. L. Berdagué, T. Thomas-Danguin, and E. Guichard. 2012. Investigating semihard cheese aroma: relationship between sensory profiles and gas chromatography-olfactometry data. Int. Dairy J. 26:41-49.

Tornambé, G., A. Cornu, I. Verdier-Metz, P. Pradel, N. Kondjoyan, G. Figueredo, S. Hulin, and B. Martin. 2008. Addition of pasture plant essential oil in milk: Influence on chemical and sensory properties of milk and cheese. J. Dairy Sci. 91:58-69.

Verdier-Metz, I., B. Martin, P. Pradel, H. Albouy, S. Hulin, M. C. Montel, and J. B. Coulon. 2005. Effect of grass-silage vs. hay diet on the characteristics of cheese: Interactions with the cheese model. Lait 85:469-480.

Viallon, C., B. Martin, I. Verdier-Metz, P. Pradel, J. P. Garel, J. B. Coulon, and J. L. Berdagué. 2000. Transfer of monoterpenes and sesquiterpenes from forages into milk fat. Lait 80:635-641. 